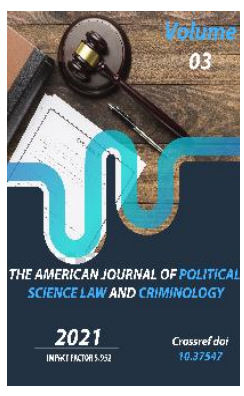

\title{
Principles In Public-Private Partnership And Their Application
}

\author{
Jaloliddin Tuychiyevich Askarov
}

Lecturer And Independent Researcher At Tashkent State University Of Law, Uzbekistan

Journal Website: https://theamericanjou rnals.com/index.php/ta jpslc

Copyright: Original content from this work may be used under the terms of the creative commons attributes 4.0 licence.

\section{ABSTRACT}

This article studies principles of public-private partnership, their current appearance and importance as well as regulatory features in the form legal act in foreign experience. Conclusions and recommendations on the regulation of digital medicine are given.

\section{KEYWORDS}

Public private partnership, the term of public-private partnership, entrepreneurship, relationships of public private partnership, features of public-private partnership.

\section{INTRODUCTION}

The introduction of market relations in our country, the widespread application of its laws in society has laid the foundation for the development of the economy of our republic. Entrepreneurs who carry out business activities as a driving force of the economy play an important role in this. The legal regulation of their activities, the basics of doing business are defined in the same way for all individuals, including foreign businessmen. The role of the principles of law in the regulation of publicprivate partnerships [1], the development of this area requires strict adherence to the legislation by the legislature and the rule of law, applying the principles. The principles of law, without exaggeration, constitute the backbone of its essential core, the essential aspect of its essence.

The principles of law emerge as the guiding idea, the starting rule, the main criteria of the process of formation, development and movement of law. 
First of all, the principles of law, which are reflected in the law, legal norms, are fully absorbed into the entire political and legal life of society, the social system of the country. They describe not only the essence of the law, but also its content, reflecting not only its internal structure, its current state, but also the process of law enforcement, the dynamics of legal activity [2].

The principles of law are a kind of basic structure (construction) on which not only legal norms, institutions or branches, but the whole legal system is based. These guiding principles serve as a guiding force for all lawmaking, law enforcement and law enforcement activities of government agencies. Adherence to them has a direct impact on the coherence, stability and efficiency of the legal system. Because the principles of law are universal, they help to ensure internal unity, harmony, and interconnectedness between different branches and institutions of law, norms, and legal relationships.

In public-private partnership relations [3], the exercise of their rights and obligations by the subjects may be carried out using general legal principles as well as special principles.

First of all, it is possible to consider the principles of public-private partnership [4] by applying the principles of common law, and thus to explain the principles of partnership.

The main meaning of the principle of legality is that the activity of the legislature - both the parliament and other law-making bodies must be carried out strictly in accordance with the law. The judicial process and the activities of all government agencies and officials involved in the implementation of the law must be in full compliance with the law. In this activity, the principle of legality is reflected in the behavior of all officials, officials and citizens in obedience to the law, in strict compliance with its requirements.

In this case, we will focus on the specific principles aimed at regulating the publicprivate partnership, first of all, it is necessary to take into account the interests of the economic sphere and their regulation in a certain way, in addition to the fact that these principles belong to the special legal field.

The citation of principles in public-private partnerships is given in various forms in the literature.

V.G. Varnavskiy, A.V. Klimenko, V.A. Korolev also set out the principles of public-private partnership [5], which are:

1) The principle of equality of interests of the parties and freedom of choice;

2) The stability of the PPP contract and the ability to change and adapt it at the same time;

3) Responsibility for compliance with the terms of the contract;

4) Competition;

5) Transparency and feedback;

6) Do not interfere;

7) Incentives and guarantees

8) Equality in relations with foreign enterprises forms.

The first special principle is the principle of equality of interests of the parties and freedom of choice. This principle is in a market economy public-private partnerships are viewed from different perspectives. This basic principle of the market economy is based on several 
aspects, namely, the choice of forms and methods to achieve equality of all economic institutions, secondly, the equality of all private companies in concluding public-private partnership agreements; reflects the freedom of choice. Although the definition of this principle of equality is applied in different areas of law, its essence is not lost, because in the opinion of H.Rakhmonkulov [6] means participation in equal legal relations.

In this regard, the principles of public-private partnership were replaced by

N.A. Ignatyuk [7] who said: possible. In addition, this activity should not be focused on sponsorship, charity and philanthropy."

It should be understood from the above statement that the relationship between the state and business entities is firstly focused on social benefits and secondly they should not be focused on sponsorship or charity during their cooperation and is reflected in the principles.

The next principle is the stability of the PPP agreement and the ability to change and adapt it at the same time, while the implementation of the agreement is a complex document, which is usually intended for a long time. is very important.

Therefore, the process of concluding a contract can take a long time, that is, the normative regulation of this principle and its reflection in the legislation is reflected in our national legislation, the Civil Code. In this case, the rights and obligations of the parties are based on the rules of state support, setting the minimum rate of mutual payments in a private partnership, as well as the content of the contract and its terms.
In addition, the issue of liability in the relations of a public-private partnership is carried out in connection with the contract concluded between the parties and its main terms. Also, as a private company-partner, it is necessary to provide services to economic agents in accordance with the terms of the contract with the state. The presence of liability in the principle should be approached only when taking responsibility arising from the contract between the private enterprise and the state, where it arises from the fact that when carrying out a particular project or program, both unilateral or bilateral obligations under the contract for the same project are not met or are not met at all.

As for the principle of competition [8] in publicprivate partnerships, this principle is also reflected in the legal relations of competition and business relations, and the relations of entities have a place in our national legislation, because if we pay attention to the definition of competition, then their independent actions exclude or limit the possibility of each of them to unilaterally influence the general conditions of commodity circulation in the commodity or financial market".

In accordance with the principle of transparency and feedback, the implementation of public-private partnerships means that the implementation of works, services and projects should be presented to the public, as well as public organizations, citizens should be aware of such actions. The basis of this principle is also set out in our Basic Encyclopedia, which guarantees that everyone has access to information and is free to seek it.

In this regard, the legislation of the Russian Federation stipulates the principle of public- 
private partnership, openness and transparency in access to information in municipal-private partnership relations, provide that the use of information does not affect the use of trade secrets or other secrets and its liability.

In addition, the principle of clarity and transparency in the process of tendering and concluding contracts in public-private partnerships is emphasized the requirements and conditions require transparency and clarity.

In the implementation of the principle of transparency, both the basic and additional, that is, the information that can be collected and provided, and the exercise of such right not only to the subjects of state control, but also to any other existing subjects should be open and transparent.

Therefore, the principle of transparency applies to public-private partnerships:

First, public and private entities are free, they have the right to receive certain types of information necessary to initiate and implement cooperation;

Second, information owners will be able to provide or disclose them to the media (other than confidential and legally protected trade secrets);

Third, government officials [9], nongovernmental non-profit organizations, and citizens should ensure that they have access to or allow access to information of interest (other than confidential and legally protected trade secrets);
Fourth, control over the information and results of projects and government programs implemented by the state in the framework of public-private partnership;

Fifth, the implementation of state control over the effective use of property provided for the implementation of projects or programs under public-private partnership;

Sixth, oversees the use of funds (budget and extra-budget funds) for the implementation of projects or programs under public-private partnerships.

It is also important that the principle of noninterference in public-private partnerships defines the boundaries of the relationship between a private enterprise and the state. decision-making in personnel and other fieldoriented activities means not interfering in influencing production.

It also allows the principle of non-interference to prevent unjustified government inspections of a private enterprise or a party that is a subject of a public-private partnership and excessive interference in its activities.

Also, when studying the principles of publicprivate partnership in the framework of business law [10], it can be seen that they are similar to the principles in this area, because the principles of this area are based on economic benefits and guarantees, ie the principle of protection of economic interests The economic interests of a business entity that produces, performs or provides services are protected by the relevant authorities in the manner prescribed by law. 


\section{CONCLUSION}

The principle of state influence on the basis of economic relations in partnership relations is explained by the fact that the economic method of influencing the economic development of the country through the command, ie the interests of the labor community, the individual in the production of goods, works and services, expanding its range and improving quality. The above-mentioned principles emphasize the relationship between the state and business entities on the basis of a partnership agreement, how it is organized and implemented, and we believe that these principles do not fully disclose this relationship.

The main reason for this is that the publicprivate partnership is not only a legal relationship agreements in the socio-economic sphere may be concluded and projects and programs that may affect the life of the society may be implemented. In addition, the above principles apply and apply the principles inherent in civil, financial, legal and administrative relations, in addition to the field of business law.

\section{REFERENCES}

1. Askarov, J. (2017). Definition and importance of public-private partnership. Review of law sciences, 1(2), 17.

2. Public-private partnership: theory and practice / V. G. Varnavsky, A. V. Klimenko, V. A. Korolev, etc .; State un$\mathrm{t}$ - Higher School of Economics. - M: Publishing house. house of the state. University - Higher School of Economics, 2010. P 15.
3. Trebilcock, M., \& Rosenstock, M. (2015). Infrastructure public-private partnerships in the developing world: Lessons from recent experience. The Journal of Development Studies, 51(4), 335-354.

4. Yescombe, E. R. (2007). Public-private partnerships: Principles of policy and finance. Oxford: Elsevier.

5. Public-private partnership: theory and practice / V. G. Varnavsky, A. V. Klimenko, V. A. Korolev, etc .; State un$\mathrm{t}$ - Higher School of Economics. - M: Publishing house. University - Higher School of Economics, 2010. P 15.

6. Zokirov I.B. Civil law: Textbook. I Part. Fifth edition. -T.: TSUL Publishing house, 2009. P 14.

7. Public-private partnership: theory and practice / V. G. Varnavsky, A. V. Klimenko, V. A. Korolev, etc .; State un$\mathrm{t}$ - Higher School of Economics. - M: Publishing house. house of the state. University - Higher School of Economics, 2010. P 15.

8. Tadjibayeva Mahsuda Discrediting as one of the signs of unfair competition // Review of law sciences. 2020. №Спецвыпуск.

https://cyberleninka.ru/article/n/discre diting-as-one-of-the-signs-of-unfaircompetition.

9. Умаров, Б. (2020). РОЛЬ ДЕЦЕНТРАЛИЗАЦИИ В КОНЦЕПЦИЯХ СОВРЕМЕННОГО УПРАВЛЕНИЯ. Review of law sciences, 1(Спецвыпуск).

10. Аскаров, Ж. (2020). ПРАВОВОЕ РЕГУЛИРОВАНИЕ АНАЛИЗ СРАВНИТЕЛЬНЫЙ СУБЪЕКТОВ 
The American Journal of Political Science Law and Criminology (ISSN - 2693-0803)

Published: July 30, 2021 | Pages: 57-62

Doi: https://doi.org/10.37547/tajpslc/Volume03Issue07-09

ПРЕДПРИНИМАТЕЛЬСТВА В СФЕРЕ

ОКАЗАНИЯ МЕДИЦИНСКИХ УСЛУГ В

ЗАРУБЕЖНЫХ СТРАНАХ. Review of

law sciences, 4(Спецвыпуск). 